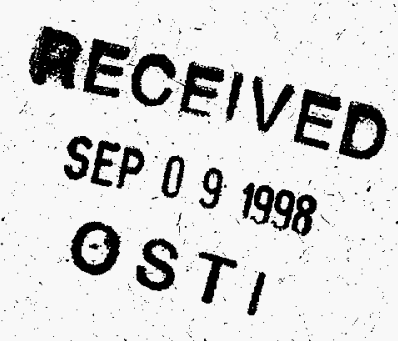

Evaluation of the Area Factor Used in the RESRAD Code for the Estimation of Airborne Contaminant Concentrations of Finite Area Sources

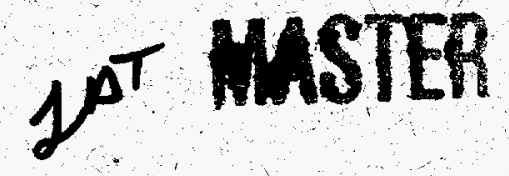

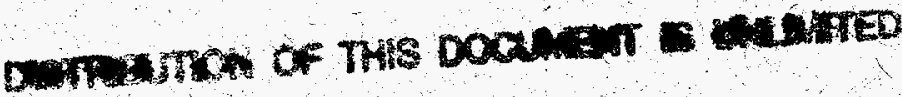

Environmental Assessment Division

Argonne National Laboratory

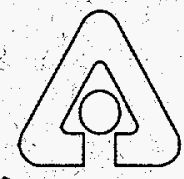

Operated by The University of Chicago, under Contract W-31-109+Eng-38, for the

United States Department of Energy 


\section{Argonne National Laboratory}

Argonne National Laboratory, with facilities in the states of Illinois and Idaho, is owned by the United States Government, and operated by the University of Chicago under the provisions of a contract with the Department of Energy.

This technical memo is a product of Argonne's Environmental Assessment Division (EAD). For information on the division's scientific and engineering activities, contact:

Director, Environmental Assessment Division

Argonne National Laboratory

Argonne, Illingis 60439-4815

Telephone (630) 252-3107

Presented in this technical memo are preliminary results of ongoing work or work that is more limited in scope and depth than that described in formal reports issu'ed by the EAD.

Publishing support services were provided by Argonne's Information and Publishing Division (for more information, see IPD's home page: http://www:ipd.anl.gov/).

\section{Disclaimer}

This report was prepared as an account of work sponsored by an agency of the United States Government. Neither the United States Government nor any agency thereof, nor any of their employees, makes any warranty, express or implied, or assumes any legal liability or responsibility for the accuracy, completeness, or usefulness of any information, apparatus, product, or process disclosed; or represents that its use would not infringe privately owned rights. Reference herein to any specific commercial product, process, or service by trade name, trademark, manufacturer, or otherwise, does not necessarily constitute or imply its endorsement, recommendation, or favoring by the United States Government or any agency thereof. The views and opinions of authors expressed herein do not necessarily state or reflect those of the United States Government or any agency thereof. 


\section{DISCLAIMER}

Portions of this document may be illegible in electronic image products. Images are produced from the best available original document. 


\title{
Evaluation of the Area Factor Used in the RESRAD Code for the Estimation of Airborne Contaminant Concentrations of Finite Area Sources
}

\author{
by Y.-S. Chang, C. Yu, and S.K. Wang* \\ Environmental Assessment Division, \\ Argonne National Laboratory, 9700 South Cass Avenue, Argonne, Illinois 60439
}

July 1998

Work sponsored by U.S. Department of Energy, Assistant Secretary for Environment, Safety and Health, Office of Environmental Policy and Assistance, and Assistant Secretary for Environmental Management, Office of Environmental Restoration

\footnotetext{
${ }^{*}$ S.K. Wang is currently associated with Kaohsiung Institute of Technology, Kaohsiung, Taiwan
} 
This report is printed on recycled paper. 


\section{CONTENTS}

NOTATION $\ldots \ldots \ldots \ldots \ldots \ldots \ldots \ldots \ldots \ldots \ldots \ldots \ldots \ldots \ldots \ldots \ldots \ldots$

ABSTRACT $\ldots \ldots \ldots \ldots \ldots \ldots \ldots \ldots \ldots \ldots \ldots \ldots \ldots \ldots \ldots \ldots \ldots \ldots \ldots$

1 INTRODUCTION $\ldots \ldots \ldots \ldots \ldots \ldots \ldots \ldots \ldots \ldots \ldots \ldots \ldots \ldots \ldots \ldots \ldots$

2 PROPOSED AREA SOURCE CONCENTRATION MODEL $\ldots \ldots \ldots \ldots \ldots \ldots \ldots \ldots$

3 RESULTS AND DISCUSSION $\ldots \ldots \ldots \ldots \ldots \ldots \ldots \ldots \ldots \ldots \ldots \ldots \ldots$

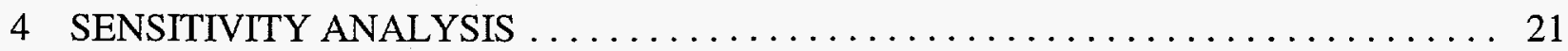

5 SUMMARY AND DISCUSSION $\ldots \ldots \ldots \ldots \ldots \ldots \ldots \ldots \ldots \ldots \ldots \ldots \ldots \ldots$

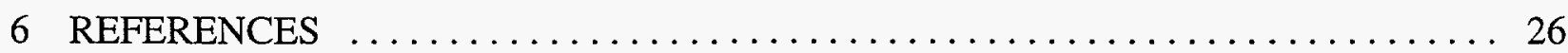

\section{FIGURES}

1 Representation of Area and Line Sources $\ldots \ldots \ldots \ldots \ldots \ldots \ldots \ldots \ldots$

2 Relative Ground-Level Concentrations for $L=1,000 \mathrm{~m}$ and

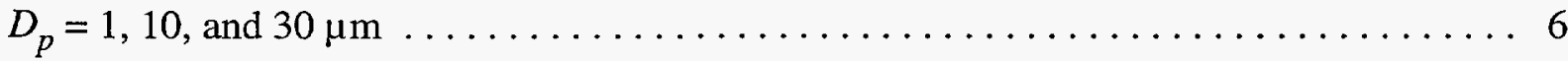

3 Relative Ground-Level Concentrations for $D_{p}=1,10$, and $30 \mu \mathrm{m} \ldots \ldots \ldots \ldots$

4 Relative Effective Source Strength and Percent Deposited over the Area Source for $D_{p}=1,10$, and $30 \mu \mathrm{m} \ldots \ldots \ldots \ldots \ldots \ldots \ldots \ldots \ldots \ldots \ldots \ldots$

5 Area Factors for $D_{p}=1,2,5,10,15$, and $30 \mu \mathrm{m} \ldots \ldots \ldots \ldots \ldots \ldots \ldots \ldots \ldots \ldots \ldots$

6 Relative Area Factors Associated with Perturbation of Rainfall Rate for

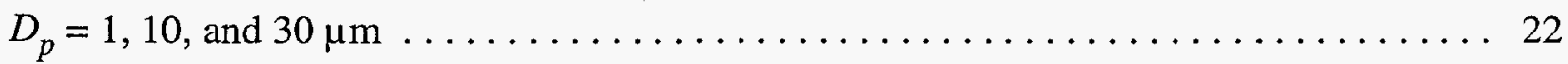

7 Relative Area Factors Associated with Perturbation of Particle Density

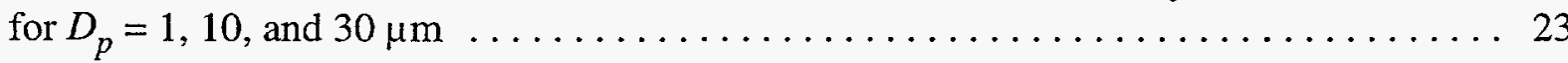

8 Relative Area Factors Associated with Perturbation of Stability Class for $D_{p}=1,10$, and $30 \mu \mathrm{m}$ 


\section{TABLES}

1 Parameters Used to Calculate Pasquill-Gifford $\sigma_{y} \ldots \ldots \ldots \ldots \ldots \ldots \ldots \ldots \ldots \ldots$

2 Parameters Used to Calculate Pasquill-Gifford $\sigma_{z} \ldots \ldots \ldots \ldots \ldots \ldots \ldots \ldots \ldots$

3 Parameter Values Used to Estimate Airborne

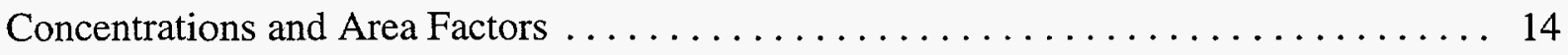

4 Coefficients Derived for the Least Square Regression Curves for Area Factors 20 


\section{NOTATION}

The following is a list of the acronyms and abbreviations, including units of measure, used in this report. Acronyms and abbreviations used only in equations, tables, or figures are defined in the respective equations, tables, or figures.

\section{ACRONYMS AND ABBREVIATIONS}

$\begin{array}{ll}\text { AMAD } & \text { activity median aerodynamic diameter } \\ \text { DOE } & \text { U.S. Department of Energy } \\ \text { EPA } & \text { U.S. Environmental Protection Agency } \\ \text { NOAA } & \text { National Oceanic and Atmospheric Administration } \\ \text { RESRAD } & \text { residual radioactive material code }\end{array}$

\section{UNITS OF MEASURE}

$\begin{array}{ll}\mathrm{cm} & \text { centimeter(s) } \\ \mathrm{g} & \text { gram(s) } \\ \mathrm{kg} & \text { kilogram(s) } \\ \mathrm{m} & \text { meter(s) } \\ \mathrm{m}^{2} & \text { square meter(s) } \\ \mathrm{m}^{3} & \text { cubic meter(s) } \\ \mu \mathrm{m} & \text { micrometer(s) } \\ \mathrm{s} & \text { second(s) } \\ \mathrm{yr} & \text { year(s) } \\ { }^{\circ} \mathrm{C} & \text { degree(s) Celsius }\end{array}$




\title{
EVALUATION OF THE AREA FACTOR USED IN THE RESRAD CODE FOR THE ESTIMATION OF AIRBORNE CONTAMINANT CONCENTRATIONS OF FINITE AREA SOURCES
}

\author{
by
}

\author{
Y.-S. Chang, C. Yu, and S.K. Wang
}

\begin{abstract}
The "area factor" is used in the RESRAD code to estimate the airborne contaminant concentrations for a finite area of contaminated soils. The area factor model used in RESRAD version 5.70 and earlier (referred to as the "old area factor") was a simple, but conservative, mixing model that tended to overestimate the airborne concentrations of radionuclide contaminants. An improved and more realistic model for the area factor (referred to here as the "new area factor") is described in this report. The new area factor model is designed to reflect sitespecific soil characteristics and meteorological conditions. The site-specific parameters considered include the size of the source area, average particle diameter, and average wind speed. Other site-specific parameters (particle density, atmospheric stability, raindrop diameter, and annual precipitation rate) were assumed to be constant. The model uses the Gaussian plume model combined with contaminant removal processes, such as dry and wet deposition of particulates. Area factors estimated with the new model are compared with old area factors that were based on the simple mixing model. In addition, sensitivity analyses are conducted for parameters assumed to be constant. The new area factor model has been incorporated into RESRAD version 5.75 and later.
\end{abstract}

\section{INTRODUCTION}

The U.S. Department of Energy (DOE) residual radioactive material code (RESRAD) is a computer code developed at Argonne National Laboratory to calculate the radiological dose to which a hypothetical on-site resident or worker would be exposed when the soil over a particular site is radiologically contaminated (Yu et al. 1993). Various exposure pathways are considered in the RESRAD code, including the inhalation of contaminated airborne particulates. For an on-site receptor, the contaminated dust resulting from on-site activities such as mechanical disturbance or natural wind erosion would be diluted because of mixing with uncontaminated off-site dust. The 
degree of dilution depends primarily on the soil characteristics and atmospheric conditions for the area of concern. For the inhalation and foliar deposition pathways in the RESRAD code, the fraction of the total ambient airborne particulate concentration that originates from the contaminated site is estimated from the monitored ambient particulate concentration data at the site or at a nearby location. This estimation involves the use of a parameter called the "area factor," which is defined as the ratio of the airborne concentration from a finite area source to the airborne concentration of an infinite area source. The area factor is less than or equal to unity because the airborne particulate concentration from a finite area source is always lower than that from an infinite area source. For example, for larger particles with high gravitational settling velocity under weak wind, emission sources upwind of some point within a square area source fail to contribute to a receptor at the downwind boundary of the site. In this case, the area factors for the area larger than the one mentioned become unity.

The area factor depends on wind speed and direction, location of receptor, particle size distribution, dry and wet deposition, and other atmospheric conditions. The area factor used in RESRAD version 5.70 and earlier, which was derived from a simple mixing model, depends only on the size of the contaminated surface area and fails to reflect any site-specific characteristics. To introduce important site-specific characteristics into the model, an alternative area factor formulation is presented. The new formulation is based on the concept of integrating airborne particulate contributions from multiple line sources that represent the area source, assuming the dispersion of the line source emissions as Gaussian. Site-specific parameters considered in the new formulation include average wind speed, the size of the contaminated site, and average particle size. The first two parameters are already incorporated into the RESRAD input database. 


\section{PROPOSED AREA SOURCE CONCENTRATION MODEL}

To calculate for on-site receptor locations the airborne concentrations of particulate emissions from a contaminated site, the site is assumed to be a square area divided into a series of line sources oriented perpendicular to the wind direction (Figure 1). The receptor $R_{l}$, which is the basis for model formulation throughout this section, is assumed to be located at the center of the downwind edge of the contaminated site. The airborne concentration $\left(\chi_{A}\right.$, measured in grams per cubic meter) at the downwind receptor $R_{l}$ in Figure 1 resulting from the square area source can be estimated by combining concentration contributions from $N$ line source segments as follows:

$$
\chi_{A}=\sum_{i=1}^{N} \chi_{L i} .
$$

If each line source is situated on the $y$-axis (which moves with a line source being evaluated), airborne concentrations from the $i^{t h}$ line source emission at the downwind receptor $R_{I}$ can be calculated. The calculation is based on the generalized crosswind finite line source Gaussian formulation (Turner 1970, 1994) as follows:

$$
\begin{aligned}
\chi_{L i}\left(x, 0, z ; H_{e}\right)= & \frac{q_{L i}^{e f f}}{\sqrt{2 \pi} u \sigma_{z}}\left\{\exp \left[-\frac{\left(z-H_{e}\right)^{2}}{2 \sigma_{z}^{2}}\right]+\exp \left[-\frac{\left(z+H_{e}\right)^{2}}{2 \sigma_{z}^{2}}\right]\right\} \\
& \int_{-L / 2 \sigma_{y}}^{L / \sigma_{y}} \frac{1}{\sqrt{2 \pi}} \exp \left(-\frac{p^{2}}{2}\right) d p,
\end{aligned}
$$

where

$$
\begin{aligned}
\chi_{L i}\left(\mathrm{x}, 0, z ; H_{e}\right)= & \text { concentration }\left(\mathrm{g} / \mathrm{m}^{3}\right) \text { at a receptor } R_{l}(\mathrm{x}, 0, \mathrm{z}) \text { resulting from the } i^{\text {th }} \text { line } \\
& \text { source with an effective release height } H_{e}(\mathrm{~m}) ; \\
q_{L i}^{e f f}= & \text { effective line source strength }[\mathrm{g} /(\mathrm{m} \cdot \mathrm{s})] ; \\
u= & \text { mean wind speed at effective release height }(\mathrm{m} / \mathrm{s}) ; \\
\sigma_{y}, \sigma_{z}= & \text { standard deviation of lateral, vertical concentration } \\
& \text { distribution }(\mathrm{m}) ; \\
p= & y / \sigma_{y} ; \text { and } \\
L= & \text { side length of square area source }(\mathrm{m}) .
\end{aligned}
$$




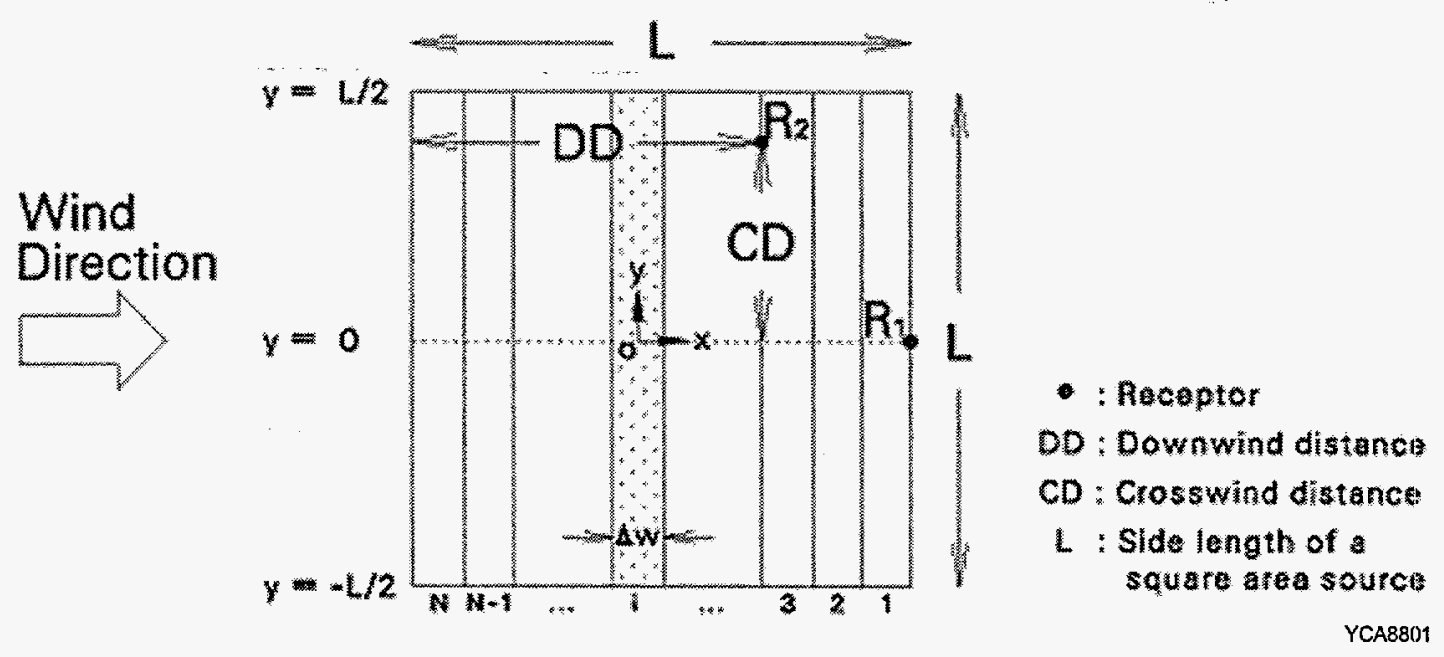

FIGURE 1 Representation of Area and Line Sources

To account for the gravitational settling of particulates, the effective release height of emission $H_{e}$ in Equation 2 is replaced by the term $\left(H_{e}-H_{v}\right)$, where $H_{v}=v_{g} x / u$ and with $v_{g}$ being the gravitational settling velocity. This substitution tilts the axis of the plume downward at an angle of $\tan ^{-1}\left(v_{g} / u\right)$. (The effects of gravitational settling are further discussed later in this section.) The value of the integral in Equation 2, an area under the Gaussian curve, is determined with a fifth-order polynomial approximation (Abramowitz and Stegun 1964). If lower and upper limits in the integral approach $-\infty$ and $+\infty$, respectively, then the integral yields unity. Also, the particulate emission of concern is considered a ground-level or near-ground-level, nonbuoyant release; therefore, the contribution of reflection of the plume is relatively smaller at the top of the mixing layer than at the surface. In fact, this is not true for an extremely unstable condition (e.g., Pasquill Stability Class A) when vigorous vertical mixing occurs; however, over a long-term period, this condition accounts for far less time than the sum of other stability conditions. Accordingly, for simplicity, the reflection of the plume at the top of the mixing layer is not considered in this study.

The area source strength, $q_{A}$, at the point of emission will gradually decrease through dry deposition and rain scavenging as the plume disperses downwind. To account for the source depletion with downwind distance, the effective line source strength at the downwind receptor $R_{1}$ of particles emitted from the $i^{\text {th }}$ line source shown in Figure 1 can be approximated as

$$
q_{L i}^{e f f}=q_{A i}^{e f f} \cdot \Delta w=\left[q_{A}-\sum_{i=1}^{i}\left(F_{D i}+F_{W i}\right)\right] \cdot \Delta w
$$


where

$$
\begin{aligned}
& \begin{aligned}
q_{A i}^{e f f}= & \text { effective area source strength at the downwind receptor } R_{I} \\
& {\left[\mathrm{~g} /\left(\mathrm{m}^{2} \cdot \mathrm{s}\right)\right] }
\end{aligned} \\
& \Delta w=\text { width of a line source, defined as the side length of square area } \\
& q_{A}=\text { area source strength at the point of emission }\left[\mathrm{g} /\left(\mathrm{m}^{2} \cdot \mathrm{s}\right)\right] \text {; and } \\
& F_{D i}, F_{W i}=\text { mass flux by dry and wet deposition on the surface of crosswind } \\
& \text { distances including downwind receptor } R_{1} \text { of the } i^{\text {th }} \text { line source } \\
& {\left[\mathrm{g} /\left(\mathrm{m}^{2} \cdot \mathrm{s}\right)\right] \text {. }}
\end{aligned}
$$

Mass fluxes $F_{D i}$ and $F_{W i}$ can be estimated by integrating products of local concentration and deposition velocities from $-\infty$ to $\infty$ in the y direction. These fluxes can be approximated by multiplying the concentration at the center of the downwind edge by the deposition velocity, because the crosswind concentration profile forms a bell shape with a flat top, as shown in Figure 2. Also note that the concentration from an infinite area source should approach a finite value; the concentration from a finite area source is divided by this finite value to determine the area factor. Accordingly, in this study, the effective source strength concept as shown in Equation 3 was adopted rather than the source exponential decay term, which fails to approach zero until the downwind distance goes to infinity. Formulations for deriving dry and wet deposition fluxes $F_{D}$ and $F_{W}$ are discussed below.

In nature, air pollutants are ultimately removed from the atmosphere by (1) dry and/or wet deposition mechanisms onto the ground surface or (2) radioactive decay or chemical transformation while being transported downwind. In this study, only dry and wet deposition are considered, and the loss of material from the plume is approximated by assuming that the source strength decreases because of dry and wet deposition. Dry deposition of an airborne material onto the earth's surface can be caused by a combination of several natural processes, such as gravitational settling, inertial impaction, molecular and turbulent diffusion, and ground absorption (by soil, water, buildings, or vegetation). The dry deposition velocity is predicted to depend on particle density, friction velocity, and surface roughness. In general, large particles $\left(D_{p}>10 \mu \mathrm{m}\right)$ are deposited predominantly by gravitational settling, whereas very small particles $\left(D_{p}<0.1 \mu \mathrm{m}\right)$ are deposited mainly by Brownian diffusion. In this study, particles ranging from 1 to $30 \mu \mathrm{m}$ in diameter are of interest; therefore, only the gravitational settling process is considered. Then, the rate of dry deposition as a result of gravitational settling, $F_{D i}\left[\mathrm{~g} /\left(\mathrm{m}^{2} \cdot \mathrm{s}\right)\right]$, is given by

$$
F_{D i}\left(x, z_{d}\right)=v_{g} \cdot \chi_{L i}\left(x, 0, z_{d} ; H_{e}\right),
$$



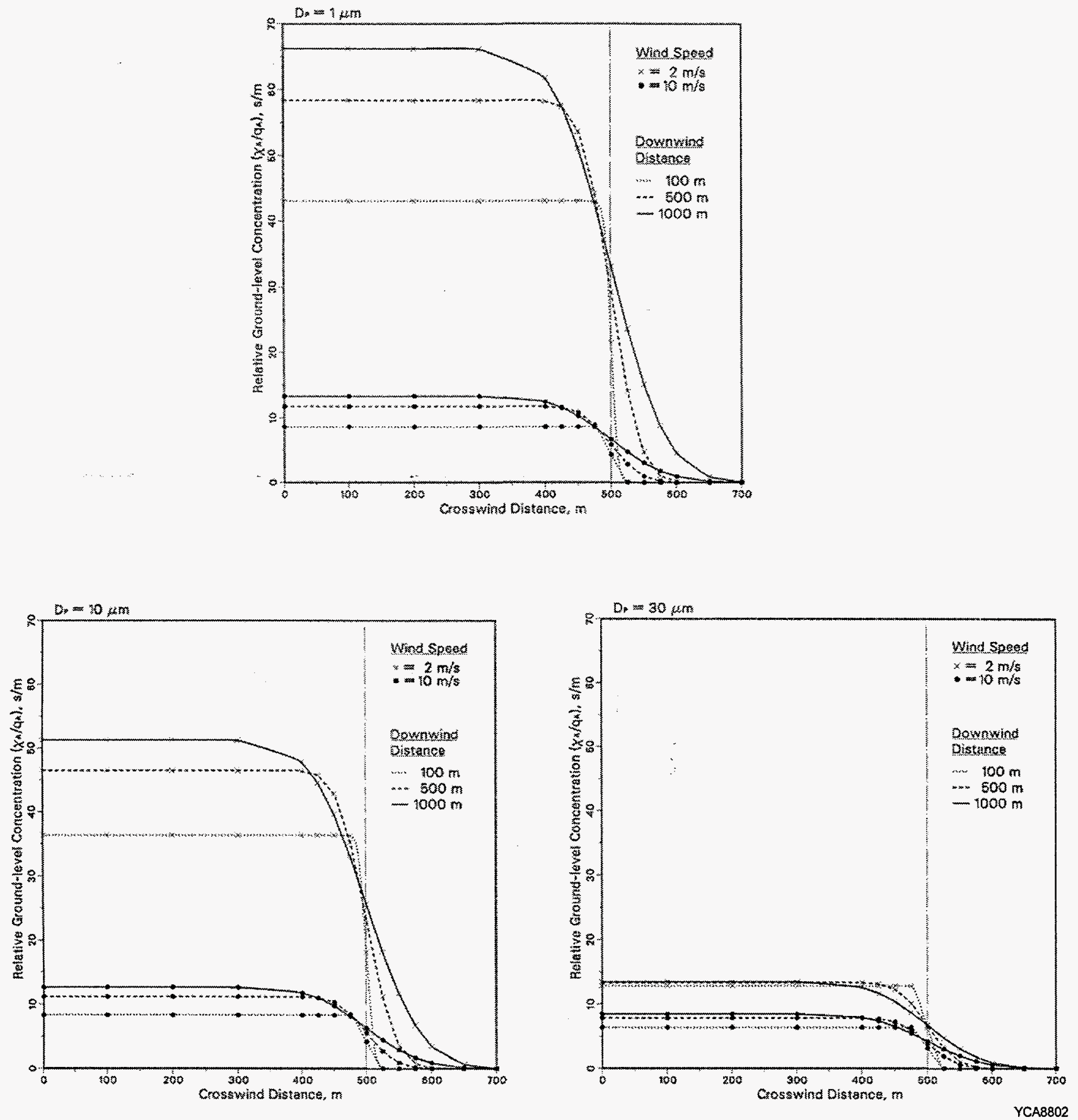

FIGURE 2 Relative Ground-Level Concentrations for $L=1,000 \mathrm{~m}$ and $D_{p}=1,10$, and $30 \mu \mathrm{m}$ 
where

$$
\begin{aligned}
& v_{g}= \text { gravitational settling velocity }(\mathrm{m} / \mathrm{s}) ; \text { and } \\
& \chi_{L i}\left(\mathrm{x}, 0, \mathrm{z}_{\mathrm{d}} ; H_{e}\right)= \text { concentration }\left(\mathrm{g} / \mathrm{m}^{3}\right) \text { at a reference height } z_{d}(\mathrm{~m}) \text { above the } \\
& \text { surface. }
\end{aligned}
$$

For particles that follow the Stokes law, the terminal gravitational settling velocity $v_{g}(\mathrm{~m} / \mathrm{s})$ can be expressed as

$$
\frac{v_{g}=\rho_{p} g D_{p}^{2}}{18 \mu_{a}}
$$

where

$$
\begin{aligned}
\rho_{p} & =\text { particle density }\left(\mathrm{kg} / \mathrm{m}^{3}\right) \\
g & =\text { gravitational acceleration }\left(9.8 \mathrm{~m} / \mathrm{s}^{2}\right) \\
D_{p} & =\text { particle diameter }(\mathrm{m}), \text { and } \\
\mu_{a} & =\text { absolute viscosity of air at sea level and } 15^{\circ} \mathrm{C}\left[1.7894 \times 10^{-5} \mathrm{~kg} /(\mathrm{m} \cdot \mathrm{s})\right]
\end{aligned}
$$

Airborne particulates are also removed by wet deposition mechanisms, including rainout (in-cloud scavenging) and washout (below-cloud scavenging by falling rain, snow, etc.). In this study, only the washout process is considered. In many cases, the local rates of removal of particulates by wet deposition, in $\mathrm{g} /(\mathrm{m} \cdot \mathrm{s})$, can be represented as a first-order process:

$$
\text { Local rate of removal }=\Lambda\left(D_{p} ; z\right) \cdot \chi_{L i}\left(x, 0, z ; H_{e}\right)
$$

where $\Lambda\left(D_{p} ; z\right)=$ washout coefficient $\left(\mathrm{s}^{-1}\right)$. This first-order representation means that the scavenging is irreversible; that is, the rate of removal depends linearly on the airborne concentration and is independent of the quantity of material scavenged previously. The wet deposition flux is the sum of wet removal from all volume elements aloft, assuming that the scavenged materials fall down as precipitation. Similar to dry deposition, the rate of wet deposition, $F_{W i}\left(x, z_{d}\right)$ in $\mathrm{g} /\left(\mathrm{m}^{2} \cdot \mathrm{s}\right)$ can be given by

$$
\left.F_{W i} x z_{d}\right)=\int_{0}^{H} \Lambda\left(D_{p} ; z\right) \cdot \chi_{L i}\left(x, 0, z ; H_{e}\right) d z=v_{w} \cdot \chi_{L i}\left(x, 0, z_{d} ; H_{e}\right)
$$


where

$$
\begin{aligned}
& H=\text { average traveling distance of a raindrop }(\mathrm{m}), \text { and } \\
& \nu_{w}=\text { wet deposition velocity }(\mathrm{m} / \mathrm{s})
\end{aligned}
$$

To formulate the wet deposition velocity, $v_{w}$, monodisperse raindrop size is assumed for sirnplicity. First, the number of raindrops falling onto the ground, $N_{r}$ [number of droplets $\left./\left(\mathrm{m}^{2} \cdot \mathrm{s}\right)\right]$, can be given by

$$
N_{r}=6.056 \times 10^{-10} \cdot R / D_{r}^{3},
$$

where

$$
\begin{aligned}
R & =\text { annual rainfall rate }(\mathrm{cm} / \mathrm{yr}), \text { and } \\
D_{r} & =\text { diameter of a raindrop }(\mathrm{m})
\end{aligned}
$$

Also, the total mass of airborne particulates swept out by each raindrop, $M(\mathrm{~g})$, can be approximated by

$$
M=A \cdot H \cdot \chi_{L i}^{a v}\left(x, 0 ; H_{e}\right)
$$

where

$$
\begin{aligned}
A= & \text { cross-sectional area of a raindrop, given by } \pi D_{r}^{2} / 4\left(\mathrm{~m}^{2}\right) ; \text { and } \\
\chi_{L i}^{a v}\left(x, 0 ; H_{e}\right)= & \text { average airborne concentration in the volume swept by a raindrop } \\
& \left(\mathrm{g} / \mathrm{m}^{3}\right) .
\end{aligned}
$$

This equation implies that all particles in the geometric volume swept out by a falling raindrop will be collected by the raindrop; that is, the value of the collection efficiency between droplets and particles is unity. Accordingly, combining Equations 8 and 9 , the total flux, $F_{W i}\left[\mathrm{~g} /\left(\mathrm{m}^{2} \cdot \mathrm{s}\right)\right]$, can be given by

$$
F_{W i}\left(x, z_{d}\right)=4.756 \times 10^{-10} \cdot R \cdot H \cdot \chi_{L i}^{a v}\left(x, 0 ; H_{e}\right) / D_{r}
$$

It is reasonable to assume that the precipitation scavenging takes place from the point of $30_{z}$, where the concentration is approximately $1 \%$ of that of the plume centerline, to the surface. For convenience, the plume height, $P H$, to account for plume tilting is defined as

$$
P H=3 \sigma_{z}-v_{g} x / u
$$


Then, $\chi_{L i}^{a v}$ can be expressed in terms of $\chi_{z d}$ in Equation 7:

$$
\chi_{L i}^{a v}\left(x, 0 ; H_{e}\right)=\frac{\chi_{L i}\left(x, 0, z_{d} ; H_{e}\right) \int_{0}^{P H}\left[\exp \left(-\frac{p_{1}^{2}}{2}\right)+\exp \left(-\frac{p_{2}^{2}}{2}\right)\right] \cdot d z}{P H \cdot\left[\exp \left(-\frac{q_{1}^{2}}{2}\right)+\exp \left(-\frac{q_{2}^{2}}{2}\right)\right]},
$$

where

$$
\begin{aligned}
& p_{1}=\left(z-H_{e}+H_{v}\right) / \sigma_{z}, \\
& p_{2}=\left(z+H_{e}-H_{v}\right) / \sigma_{z}, \\
& q_{1}=\left(z_{d}-H_{e}+H_{v}\right) / \sigma_{z}, \text { and } \\
& q_{2}=\left(z_{d}+H_{e}-H_{v}\right) / \sigma_{z} .
\end{aligned}
$$

As in Equation 2, the value of the integral can be calculated with a fifth-order polynomial approximation. Combining Equations 11 and 12 into Equation 10, the rate of wet deposition can be rewritten in terms of wet deposition velocity $v_{w}$ and concentration at the reference height $z_{d}$, as in the calculation for dry deposition.

Lateral and vertical dispersion coefficients $\sigma_{y}$ and $\sigma_{z}$ are estimated on the basis of the formulae used in the Industrial Source Complex model (EPA 1995). Equations that approximately fit the Pasquill-Gifford curves (Turner 1970,1994) are introduced to calculate $\sigma_{y}$ and $\sigma_{z}(\mathrm{~m})$ as a function of downwind distance $(\mathrm{km})$ for the rural mode. The $\sigma_{y}$ coefficient can be calculated by

$$
\sigma_{y}=465.11628 \cdot x \cdot \tan (T H),
$$

where

$$
T H=0.017453293 \cdot[c-d \cdot \ln (x)] .
$$

Also, $\sigma_{z}$ can be computed as

$$
\sigma_{z}=a \cdot x^{b}
$$

For the above equations, the coefficients $c$ and $d$ for $\sigma_{y}$ and $a$ and $b$ for $\sigma_{z}$ are presented in Tables 1 and 2 , respectively. 
TABLE 1 Parameters Used to Calculate Pasquill-Gifford $\sigma_{y}$

\begin{tabular}{ccc}
\hline & \multicolumn{2}{c}{$\sigma_{y}=465.11628(x) \tan (T H)^{*}$} \\
Pasquill & $T H=0.017453293[c-d \cdot \ln (x)]$ \\
\cline { 2 - 2 } $\begin{array}{c}\text { Stability } \\
\text { Class }\end{array}$ & $c$ & $d$ \\
\hline & & \\
A & 24.1670 & 2.5334 \\
B & 18.3330 & 1.8096 \\
C & 12.5000 & 1.0857 \\
D & 8.3330 & 0.72382 \\
E & 6.2500 & 0.54287 \\
F & 4.1667 & 0.36191 \\
\hline \multicolumn{3}{c}{$\sigma_{y}$ is expressed in meters, and $x$ is the } \\
downwind distance, in kilometers. \\
Source: EPA (1995).
\end{tabular}

Finally, numerical calculations were made after all components were incorporated into the model. Integrations were made in succession from the nearest line source to the farthest from the receptor $R_{1}$. If the receptor height $(z)$ and the reference height $(z d$ are the same, combining and rewriting Equations 2 and 3 shows that the concentration at the receptor $R_{I}$ resulting from the $i^{\text {th }}$ line source appears in both sides, which can be readily solved by transposing,

From the first line source, $\quad \chi_{L 1}=q_{L}^{e f f} \cdot R H S_{1}=\left(q_{A}-\chi_{L I} v_{T 1}\right) \cdot \Delta w \cdot R H S_{1}$

From the second line source, $\quad \chi_{L 2}=q_{L 2}^{e f f} \cdot R H S_{2}=\left[q_{A}-\left(\chi_{L I} v_{T 1}+\chi_{L 2} v_{T 2}\right)\right] \cdot$

$$
\Delta w \cdot R H S_{2}
$$

From the $i^{\text {th }}$ line source,

$$
\begin{aligned}
\chi_{L i}= & q_{L i}^{e f f} \cdot R H S_{i}=\left[q_{A}-\right. \\
& \left.\left(\chi_{L 1} v_{T 1}+\chi_{L 2} v_{T 2} \cdots+\chi_{L i} v_{T i}\right)\right] \cdot \Delta w \cdot R H S_{i}
\end{aligned}
$$

where

$$
\begin{aligned}
v_{T i} & =v_{g i}+v_{w i}(\mathrm{~m} / \mathrm{s}) ; \text { and } \\
R H S_{i} & =\text { (right hand side of Equation } 2) / q_{L i}^{e f f} .
\end{aligned}
$$


TABLE 2 Parameters Used to Calculate Pasquill-Gifford $\sigma_{z}{ }^{*}$

\begin{tabular}{|c|c|c|c|}
\hline \multirow[b]{2}{*}{$\begin{array}{c}\text { Pasquill } \\
\text { Stability Class } \\
\end{array}$} & \multirow[b]{2}{*}{$x$} & \multicolumn{2}{|c|}{$\sigma_{\mathrm{z}}=a \cdot x^{b}$} \\
\hline & & $a$ & $b$ \\
\hline \multirow[t]{9}{*}{$\mathrm{A}^{+}$} & $<0.10$ & 122.800 & 0.94470 \\
\hline & $0.10-0.15$ & 158.080 & 1.05420 \\
\hline & $0.16-0.20$ & 170.220 & 1.09320 \\
\hline & $0.21-0.25$ & 179.520 & 1.12620 \\
\hline & $0.26-0.30$ & 217.410 & 1.26440 \\
\hline & $0.31-0.40$ & 258.890 & 1.40940 \\
\hline & $0.41-0.50$ & 346.750 & 1.72830 \\
\hline & $0.51-3.11$ & 453.850 & 2.11660 \\
\hline & $>3.11$ & $\dagger$ & $\dagger$ \\
\hline \multirow[t]{3}{*}{$\mathrm{B}^{+}$} & $<0.20$ & 90.673 & 0.93198 \\
\hline & $0.21-0.40$ & 98.483 & 0.98332 \\
\hline & $>0.40$ & 109.300 & 1.09710 \\
\hline $\mathrm{C}^{+}$ & All & 61.141 & 0.91465 \\
\hline \multirow[t]{6}{*}{$\mathrm{D}$} & $<0.30$ & 34.459 & 0.86974 \\
\hline & $0.31-1.00$ & 32.093 & 0.81066 \\
\hline & $1.01-3.00$ & 32.093 & 0.64403 \\
\hline & $3.01-10.00$ & 33.504 & 0.60486 \\
\hline & $10.01-30.00$ & 36.650 & 0.56589 \\
\hline & $>30.00$ & 44.053 & 0.51179 \\
\hline \multirow[t]{9}{*}{$\mathrm{E}$} & $<0.10$ & 24.260 & 0.83660 \\
\hline & $0.10-0.30$ & 23.331 & 0.81956 \\
\hline & $0.31-1.00$ & 21.628 & 0.75660 \\
\hline & $1.01-2.00$ & 21.628 & 0.63077 \\
\hline & $2.01-4.00$ & 22.534 & 0.57154 \\
\hline & $4.01-10.00$ & 24.703 & 0.50527 \\
\hline & $10.01-20.00$ & 26.970 & 0.46713 \\
\hline & $20.01-40.00$ & 35.420 & 0.37615 \\
\hline & $>40.00$ & 47.618 & 0.29592 \\
\hline \multirow[t]{10}{*}{ F } & $<0.20$ & 15.209 & 0.81558 \\
\hline & $0.21-0.70$ & 14.457 & 0.78407 \\
\hline & $0.71-1.00$ & 13.953 & 0.68465 \\
\hline & $1.01-2.00$ & 13.953 & 0.63227 \\
\hline & $2.01-3.00$ & 14.823 & 0.54503 \\
\hline & $3.01-7.00$ & 16.187 & 0.46490 \\
\hline & $7.01-15.00$ & 17.836 & 0.41507 \\
\hline & $15.01-30.00$ & 22.651 & 0.32681 \\
\hline & $30.01-60.00$ & 27.074 & 0.27436 \\
\hline & $>60.00$ & 34.219 & 0.21716 \\
\hline \multicolumn{4}{|c|}{$\begin{array}{l}\text { * } a_{z} \text { is expressed in meters, and } x \text { is expressed in } \\
\text { kilometers. }\end{array}$} \\
\hline \multicolumn{4}{|c|}{$\begin{array}{l}+ \text { If the calculated value of } \sigma_{z} \text { exceeds } 5,000 \mathrm{~m}, \sigma_{z} \text { is set } \\
\text { to } 5,000 \mathrm{~m} .\end{array}$} \\
\hline \multicolumn{4}{|c|}{$\dagger \sigma_{z}$ is equal to $5,000 \mathrm{~m}$. } \\
\hline Source: EPA (1S & & & \\
\hline
\end{tabular}


The model first divides an area source into 10- and 11-line sources, computes the concentration for each line $\left(\chi_{L i}\right)$ at the receptor $R_{I}$, and sums the concentrations to arrive at the total concentration $\left(\chi_{A}\right)$ resulting from the entire area source. Then, if the relative difference of concentrations between 10- and 11-line sources is within a given tolerance (e.g., $10^{-4}$ ), the iterative procedures will be terminated. If not, successive iterations continue with further subdivisions in increments of 10 (e.g., $20 / 21,30 / 31,40 / 41)$ until the prescribed convergence condition is satisfied. For computational economy, the maximum number of line sources is limited to 10,000 . 


\section{RESULTS AND DISCUSSION}

The area factor can be defined as the ratio of the airborne concentration from a finite area source to that from an infinite area source. The methodology used to estimate the area factors is based on the notion that once released into the ambient air, all particulate matter would eventually be removed from the atmosphere by dry and/or wet deposition. The model first calculates the concentrations at the downwind receptor $R_{1}$ by increasing the square area source until concentration values are leveled off, that is, approach the maximum values. Then the area factors for square area sources are estimated by dividing their respective concentrations by the maximum concentrations. Some important factors that affect the airborne concentrations are area size, wind speed, wind direction, particle size, location of the receptor, stability class, rainfall rate, and raindrop size.

To illustrate the effects of these factors, the new model was implemented for four wind speeds $(1,2,5$, and $10 \mathrm{~m} / \mathrm{s}$ at the measurement height [usually $10 \mathrm{~m}$ ]) and six particle diameters (1, $2,5,10,15$, and $30 \mu \mathrm{m}$ ). Nine square area sources that have side lengths ranging from 1 to $100,000 \mathrm{~m}$ and that are oriented perpendicular to the wind direction are analyzed in this study. It is assumed that particles from a source area are emitted into the atmosphere by on-site activities such as mechanical disturbances or wind erosion. This assumption implies that particles are airborne, irrespective of the mechanism of dust generation, and are subsequently subject to a wind stream. For a finite source area, the average airborne concentration can be estimated by integrating the groundlevel airborne concentrations over the entire source area. However, this value depends on the frequencies of occurrence of different wind directions and speeds. For simplicity, it is conservative to take the maximum local airborne concentration, that is, the concentration at the center of the downwind edge (receptor $R_{1}$ in Figure 1), as the average concentration. The airborne concentrations presented in the rest of the report are the values predicted for the locations at the center of the downwind edge, unless otherwise stated.

The depletion of emission sources associated with radionuclide decay is neglected in the current study. Also, the effective release height $\left(H_{e}\right)$, receptor height $(z)$, and reference height $\left(z_{r}\right)$ are assumed to be zero, that is, at the surface. Parameter values used to estimate airborne concentrations and area factors were selected for typical sites in the United States, where possible (Table 3). On the basis of annual averages for more than 300 National Weather Service stations in the United States, the neutral conditions (represented by Pasquill Class D) occur almost one-half of the observations, while stable (Classes E and F) and unstable (Classes A, B, and C) conditions occur about one-third and one-sixth of the time, respectively (National Oceanic and Atmospheric Administration [NOAA] 1976). Therefore, in this study, neutral stability (Class D) was assumed.

To illustrate the effects of wind speed and particle size on the concentrations at various receptor locations within the site, the relative ground-level concentrations, $\chi_{A} / q_{A}$, for a $1,000 \times 1,000 \mathrm{~m}$ area source are shown in Figure 2 for various crosswind and downwind locations 


\section{TABLE 3 Parameter Values Used to Estimate Airborne Concentrations and Area Factors}

\begin{tabular}{lll}
\hline \multicolumn{1}{c}{ Parameter } & Values Used & Reference \\
\hline Rainfall rate & $R=100 \mathrm{~cm} / \mathrm{yr}$ & Miller and Thompson (1970) \\
Particle density & $\rho_{p}=2,650 \mathrm{~kg} / \mathrm{m}^{3}$ & Brady (1974) \\
Stability class & $\mathrm{D}$ (Neutral) & NOAA (1976) \\
Diameter of raindrop & $D_{r}=10^{-3} \mathrm{~m}$ & Miller and Thompson (1970) \\
\hline
\end{tabular}

(Figure 1). Concentrations at the off-axis receptor (e.g., receptor $R_{2}$ in Figure 1) can be estimated by integrating the area source upwind of the receptor with the modification of integration limits in Equation 2. Figure 2 shows relative ground-level concentrations for particle diameters of 1,10 , and $30 \mu \mathrm{m}$, respectively, for cases with wind speeds of 2 and $10 \mathrm{~m} / \mathrm{s}$. The downwind distances presented in the figure are 100,500 , and 1,000 $\mathrm{m}$ (i.e., downwind edge) from the upwind edge of the square source area. As shown in Figure 2, the airborne concentrations increase with the downwind distances and decrease with the crosswind distances from the centerline of the area source parallel to the wind direction. The airborne concentrations along the crosswind distance do not vary significantly except at the locations very close to the crosswind edges of the source area, where the airborne concentrations are predicted to be approximately $50 \%$ lower than those at the centerline locations. Also, concentration distributions show symmetry centering around the crosswind edge. (As mentioned in Equation 3, mass fluxes by depositions can be approximated only with concentration at the downwind receptor $R_{1}$ without integrating local concentrations along the crosswind distances because of the concentration profile described above.) The airborne concentrations near the crosswind edge are more affected by downwind distance associated with edge effects from the line source. In general, the particle suspension rate driven by wind erosion increases as the wind speed increases. However, the increase in emissions caused by higher wind speed is partially offset by the dilution by the higher wind speed.

To illustrate the effects of the size of the square source area on the airborne concentration, the relative ground-level concentrations $\chi_{A} / q_{A}$ resulting from square area sources of various sizes are shown in Figure 3 for particles 1,10 , and $30 \mu \mathrm{m}$ in diameter. In general, the $\chi_{A} / q_{A}$ values increase monotonically with the size of the square area source and decrease with wind speed and particle diameter. If the source area is large enough, the airborne concentrations reach a maximum value and do not increase even if the size of the area source is further increased. This means that the airborne concentration thus calculated is similar to that of an area source of infinite size. For smaller particles $\left(D_{p}=1 \mu \mathrm{m}\right)$, the airborne concentrations reach their maximums at side lengths of around $100,000 \mathrm{~m}$ or more, being primarily scavenged by precipitation. On the other hand, for particles of $30 \mu \mathrm{m}$ in diameter and low wind speed, emissions from sources located more than $1,000 \mathrm{~m}$ upwind 

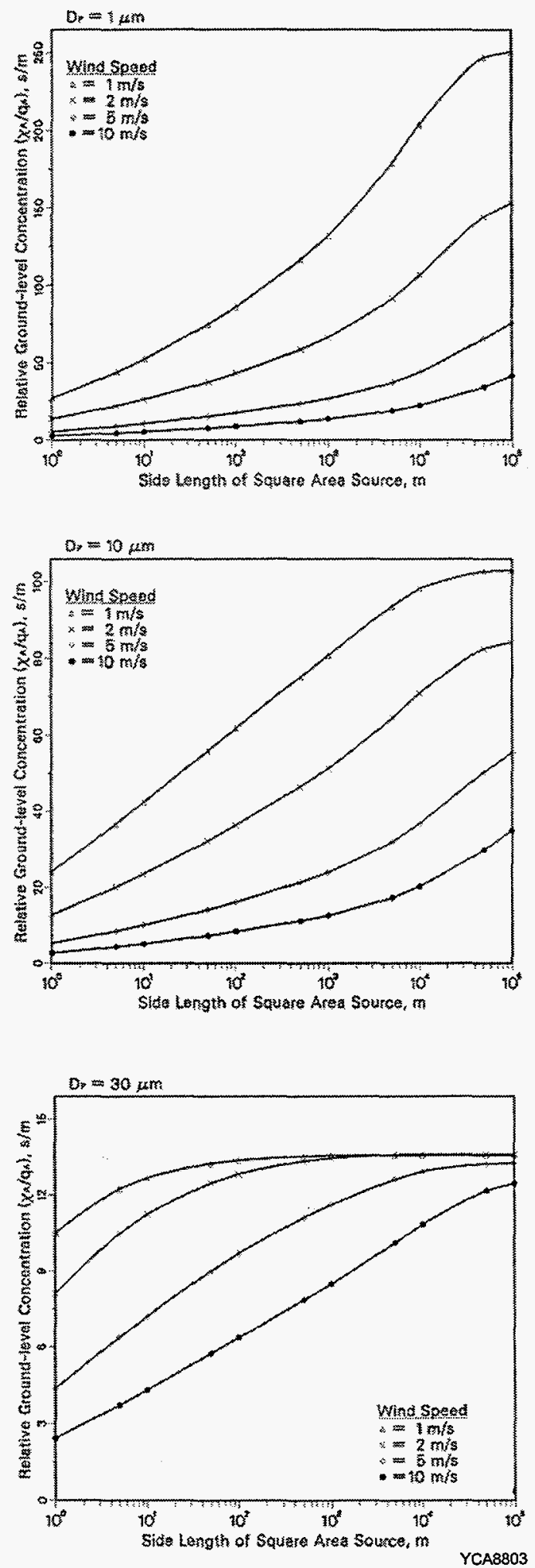

FIGURE 3 Relative Ground-Level Concentrations for $D_{p}=1,10$, and $30 \mu \mathrm{m}$ 
do not contribute to concentrations at the downwind receptor location because of high gravitational settling velocity.

To examine the relationship between virtual emissions and depositions within the area source, relative effective source strength and percentage deposited are depicted in Figure 4 . The relative effective source strength, $\mathrm{q}_{\mathrm{eff}} / \mathrm{q}_{\mathrm{A}}$, is defined as the ratio of the effective source strength at the downwind edge to the source strength at the upwind edge of the square area. The percentage deposited is defined as the total mass deposited by dry and wet deposition up to the downwind edge divided by the total emissions within the site. Note that $q_{\text {eff }} / q_{A}=0$ does not necessarily mean $100 \%$ deposition of particulates emitted, because airborne particulates still exist over the site. As shown in Figure 4, the wet deposition process is dominant over dry deposition for smaller particles $\left(D_{p}=1 \mu \mathrm{m}\right)$. For particles of $10 \mu \mathrm{m}$ or larger in diameter, gravitational settling is the major removal pathway. The side length of the square area source where emission from the upwind edge is almost depleted when the plume passes over the downwind edge is more than $100,000 \mathrm{~m}$ for a particle diameter of $1 \mu \mathrm{m}$ and wind speed of $1 \mathrm{~m} / \mathrm{s}$. On the other hand, the side length size is approximately $1,000 \mathrm{~m}$ for the case of a particle diameter of $30 \mu \mathrm{m}$ and wind speed of $1 \mathrm{~m} / \mathrm{s}$. More particles are deposited at lower wind speeds than at higher wind speeds because at lower wind speeds there are more chances for particles to be removed by dry or wet depositions before they pass over the downwind edge. It is interesting to note that for particles $1 \mu \mathrm{m}$ in diameter, deposition can be ignored for area sources with side lengths of $1,000 \mathrm{~m}$ or less.

The area factors for cases with various wind speeds and particle diameters are shown in Figure 5. General trends for area factors are similar to those for relative ground-level concentrations expressed as $\chi_{A} / q_{A}$ (Figure 3). A physical interpretation for the small area factors is that dilution by the uncontaminated dust blown in from off-site is significant for the case of small particles and high wind speeds. On the other hand, for cases with large particles and low wind speeds, deposition becomes significant, and a maximum airborne concentration can be reached if the source area is sufficiently large. Accordingly, the larger the area factor, the more emitted particulates are removed before reaching the downwind edge.

The old area factors used in the RESRAD code are also plotted in Figure 5. The area factor is approximated by $A^{1 / 2} /\left(A^{1 / 2}+D L\right)$, where $A$ is the area of contaminated site $\left(\mathrm{m}^{2}\right)$ and $D L$ is the dilution length (m). Although $D L$ depends on the wind speed, mixing height, resuspension rate, and thickness of the resuspendable dust layer (Appendix A in Gilbert et al. 1983), the geometric mean of the estimates of lower and upper bounds of $D L$ is used as a default value. In the RESRAD code, the geometric mean $(3 \mathrm{~m}$ ) of 0.03 and $250 \mathrm{~m}$ (which correspond to the surface roughness and the height of the stable atmospheric layer, respectively) is assumed to be the default dilution length in predicting the airborne concentration from a finite source area. As shown in Figure 5, the old area factors used in the RESRAD code are larger than those obtained in the new model, except for the case of large particles $\left(D_{p}=30 \mu \mathrm{m}\right)$ and low wind speed. Results show that the dilution length of 

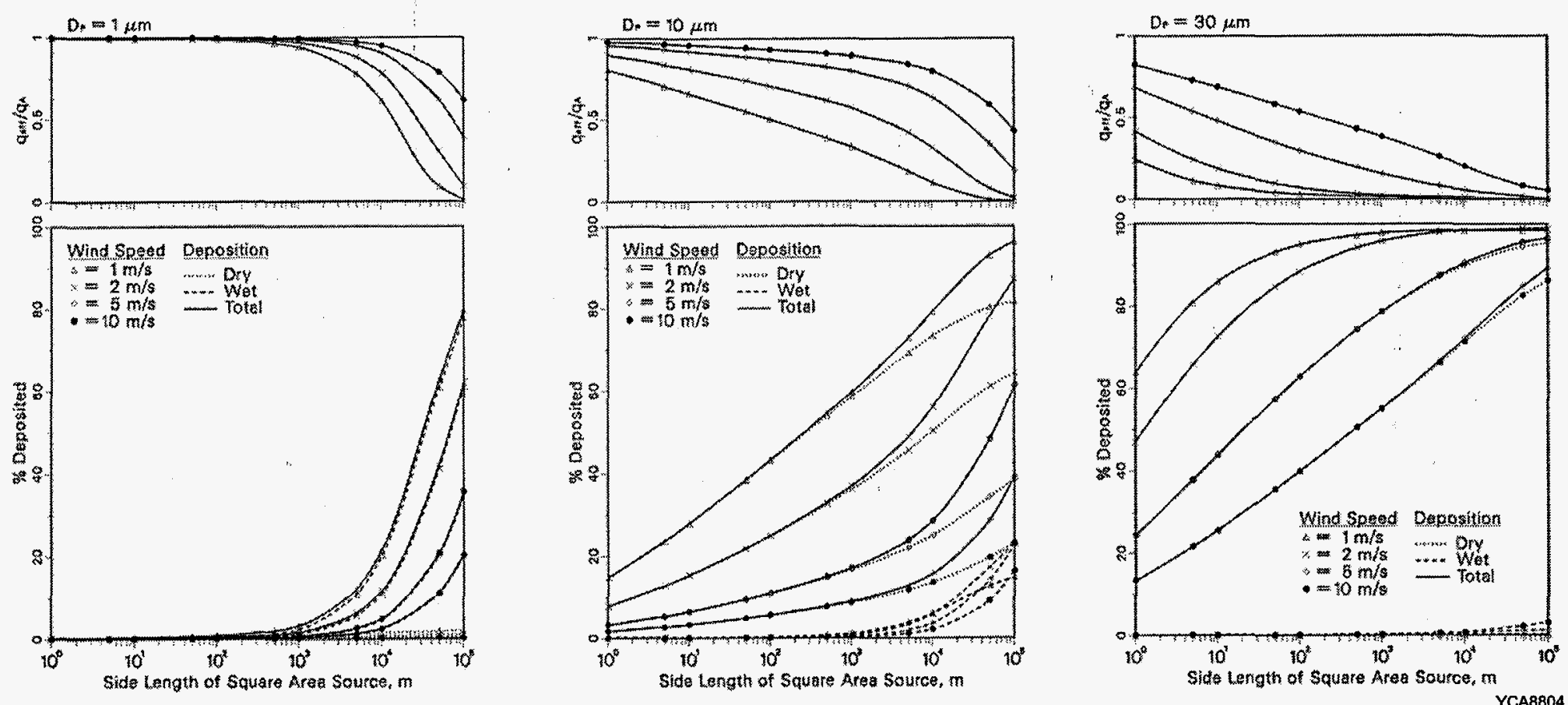

FIGURE 4 Relative Effective Source Strength and Percent Deposited over the Area Source for $D_{p}=1,10$, and $30 \mu \mathrm{m}$ 

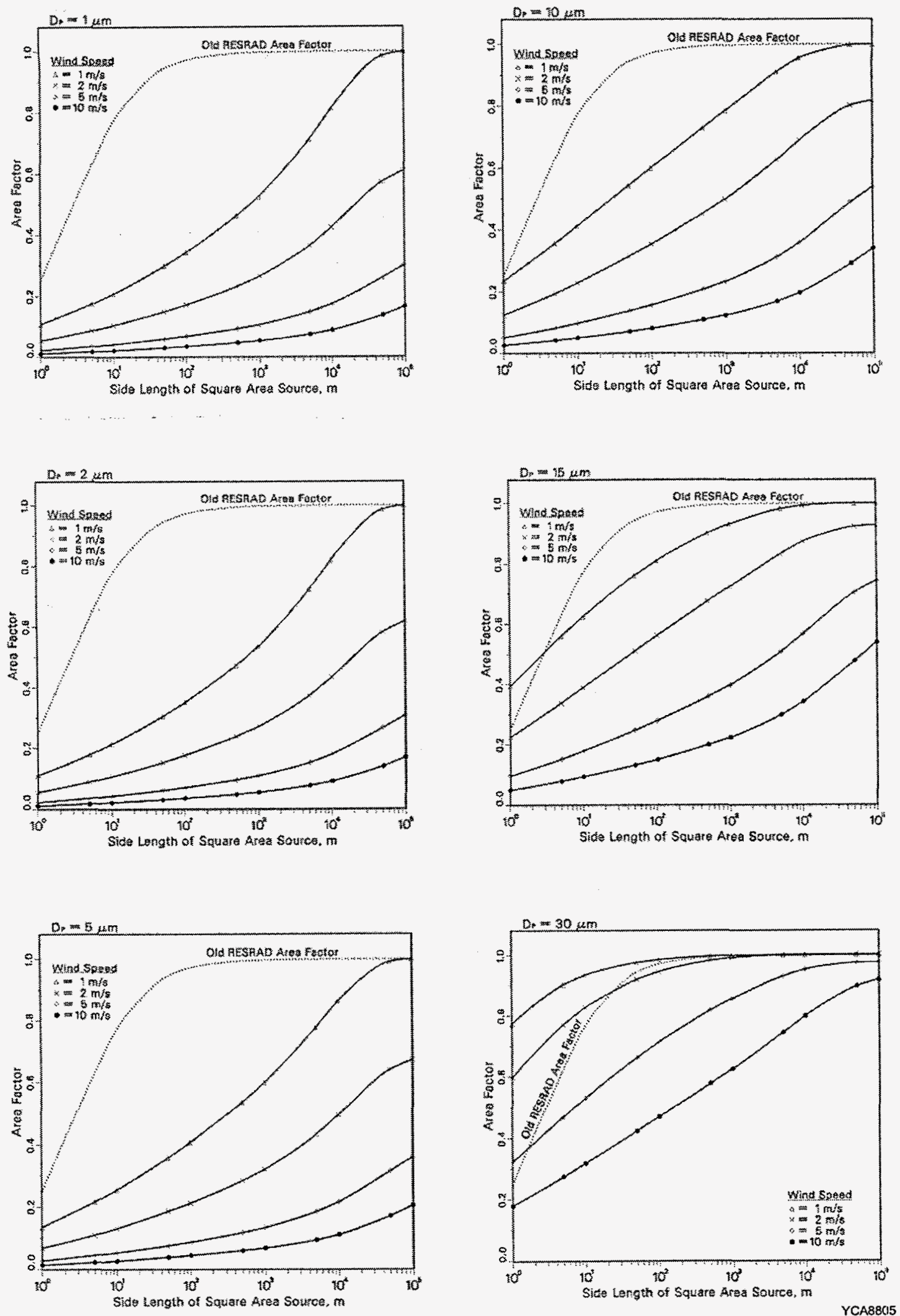

FIGURE 5 Area Factors for $D_{p}=1,2,5,10,15$, and $30 \mu \mathrm{m}$ 
$3 \mathrm{~m}$ as assumed in the RESRAD code provides a reasonably conservative estimate of the airborne concentrations for respirable particle sizes of $1-10 \mu \mathrm{m}$.

For direct use in the RESRAD code application, functional expressions are needed to compute the new area factor associated with a finite area source. The desired feature of the functional expression is a sigmoidal behavior with characteristics approaching 0 and 1 of area factors as the side length of source area varies from $0 \mathrm{~m}$ to $\infty$. Two candidates represented by the logistic growth rate function (Snedecor and Cochran 1980) and the hyperbolic tangent function were tested by regression. The former function was selected because it provides a remarkably good fit to the cases under study and a much better fit than the latter. The equation used to fit the new area factors can be written as

$$
\text { Area Factor }=\frac{a}{1+b(\sqrt{\mathrm{A}})^{c}}
$$

where $\mathrm{A}=$ area of the contaminated zone. The coefficients $\mathrm{a}, \mathrm{b}$, and $\mathrm{c}$ for regression curves for the new area factors and related correlation coefficients are presented in Table 4 . The regression curve fits very well for the side length $(\sqrt{\mathrm{A}})$ of the square area source ranging from 1 to $10,000 \mathrm{~m}$ because more weights are assigned to points within that range. 
TABLE 4 Coefficients Derived for the Least Square Regression Curves for Area Factors*

\begin{tabular}{|c|c|c|c|c|c|}
\hline \multirow{3}{*}{$\begin{array}{c}\text { Particle } \\
\text { Diameter } \\
(\mu \mathrm{m})\end{array}$} & \multirow{3}{*}{$\begin{array}{l}\text { Wind } \\
\text { Speed } \\
(\mathrm{m} / \mathrm{s})\end{array}$} & & & \multicolumn{2}{|l|}{$a$} \\
\hline & & \multicolumn{2}{|c|}{ Area Factor ${ }^{+}=$} & $1+b(\sqrt{\mathrm{A}})^{c}$ & \\
\hline & & $a$ & $b$ & $c$ & $\begin{array}{l}\text { Correlation } \\
\text { Coefficient }\end{array}$ \\
\hline \multirow[t]{4}{*}{1} & 1 & 1.9005 & 14.1136 & -0.2445 & 0.9978 \\
\hline & 2 & 1.6819 & 25.5076 & -0.2278 & 0.9991 \\
\hline & 5 & 0.7837 & 31.5283 & -0.2358 & 0.9946 \\
\hline & 10 & 0.1846 & 14.6689 & -0.2627 & 0.9732 \\
\hline \multirow[t]{4}{*}{2} & 1 & 1.8383 & 13.2106 & -0.2451 & 0.9979 \\
\hline & 2 & 1.6643 & 24.3606 & -0.2273 & 0.9992 \\
\hline & 5 & 0.8301 & 32.1641 & -0.2339 & 0.9949 \\
\hline & 10 & 0.1992 & 15.2539 & -0.2598 & 0.9750 \\
\hline \multirow[t]{4}{*}{5} & 1 . & 1.5112 & 8.7288 & -0.2528 & 0.9982 \\
\hline & 2 & 1.4913 & 17.2749 & -0.2264 & 0.9992 \\
\hline & 5 & 1.1050 & 33.8232 & -0.2266 & 0.9966 \\
\hline & 10 & 0.3174 & 19.9297 & -0.2500 & 0.9838 \\
\hline \multirow[t]{4}{*}{10} & 1 & 1.1445 & 3.4160 & -0.2891 & 0.9987 \\
\hline & 2 & 1.1396 & 6.9377 & -0.2451 & 0.9993 \\
\hline & 5 & 1.6353 & 25.4614 & -0.2112 & 0.9990 \\
\hline & 10 & 1.2075 & 39.4658 & -0.2212 & 0.9955 \\
\hline \multirow[t]{4}{*}{15} & 1 & 1.0273 & 1.6289 & -0.3945 & 0.9996 \\
\hline & 2 & 1.0469 & 3.1582 & -0.2813 & 0.9993 \\
\hline & 5 & 1.5252 & 11.8208 & -0.2085 & 0.9995 \\
\hline & 10 & 2.5496 & 40.9663 & -0.2012 & 0.9988 \\
\hline \multirow[t]{4}{*}{30} & 1 & 1.0000 & 0.2656 & -0.5937 & 0.9998 \\
\hline & 2 & 1.0059 & 0.7305 & -0.5352 & 0.9995 \\
\hline & 5 & 1.0781 & 2.0215 & -0.2979 & 0.9980 \\
\hline & 10 & 1.1325 & 4.4736 & -0.2483 & 0.9996 \\
\hline
\end{tabular}

* The regression curve fits well for the side length $(\sqrt{\mathrm{A}})$ of the square area source ranging from 1 to $10,000 \mathrm{~m}$.

+ Where $\sqrt{\mathrm{A}}$ is the length of the side of the square area source, in meters. 


\section{SENSITIVITY ANALYSIS}

To perform sensitivity analyses for assumed parameters, four cases were simulated as follows (the Base Case is the original simulation):

- Case 1: Annual rainfall rate $(R)$,

- Case 2: Diameter of a raindrop $\left(D_{r}\right)$,

- Case 3: Particle density $\left(D_{p}\right)$, and

- Case 4: Atmospheric stability class.

For Cases 1 to 3,100\% perturbation upward and downward for assumed parameter values was tested. For Case 4, the most unstable (Class A) and most stable (Class F) classes were tested. In fact, assuming $100 \%$ increase in annual rainfall rate for Case 1 provides identical results to $100 \%$ decrease in diameter of a raindrop for Case 2, or vice versa. This situation can be seen in Equation 10, where the annual rainfall rate $(R)$ is inversely related to the raindrop diameter $\left(D_{r}\right)$.

Relative area factors, which represent the ratio of area factor resulting from parameter perturbations to that for the Base Case, are presented in Figures 6 to 8 for perturbations in rainfall rate, particle density, and atmospheric stability class, respectively. Relative area factors are predicted to be relatively insensitive to changes in annual rainfall rate and, as shown in Figure 6, vary approximately 20,5 , and $0 \%$ for 1,10 , and $30 \mu \mathrm{m}$, respectively. This result suggests that for smaller particles, wet deposition plays an important role in removal, while for larger particles, gravitational settling is the major removal process. Perturbation of particle density for Case 3 is more sensitive than that of annual rainfall rate for Case 1. As shown in Figure 7, the sensitivity increases with particle size. Although considerable range in particle density may be observed, the values for most mineral soils usually vary between the narrow limits of 2,600 and $2,750 \mathrm{~kg} / \mathrm{m}^{3}$ (Brady 1974). Some mineral topsoils high in organic matter may drop to $2,400 \mathrm{~kg} / \mathrm{m}^{3}$ or lower. Nevertheless, for general calculations, the average arable surface soil may be considered to have a particle density of about $2,650 \mathrm{~kg} / \mathrm{m}^{3}$. For Case 4 , the area factors are most sensitive, especially for smaller particles (Figure 8). This result means that smaller particles are more affected by atmospheric turbulence than larger particles. However, the most unstable (Class A) and most stable (Class F) cases are characterized by conditions under strong solar insolation and under clear nights, respectively, and for both cases, under weak wind. In general, these conditions prevail several hours per day at most, so the sum of the neutral and near-neutral conditions (Classes $\mathrm{C}, \mathrm{D}$, and $\mathrm{E}$ ) is much greater than the sum of extreme conditions (Classes $\mathrm{A}$ and $\mathrm{F}$ ). Therefore, over the long term (e.g., annual average concentrations), the use of neutral stability (Class D) in this study is reasonable because the area factor averaged over site-specific distributions of stability classes is believed to be close to the one calculated only from the neutral stability. 

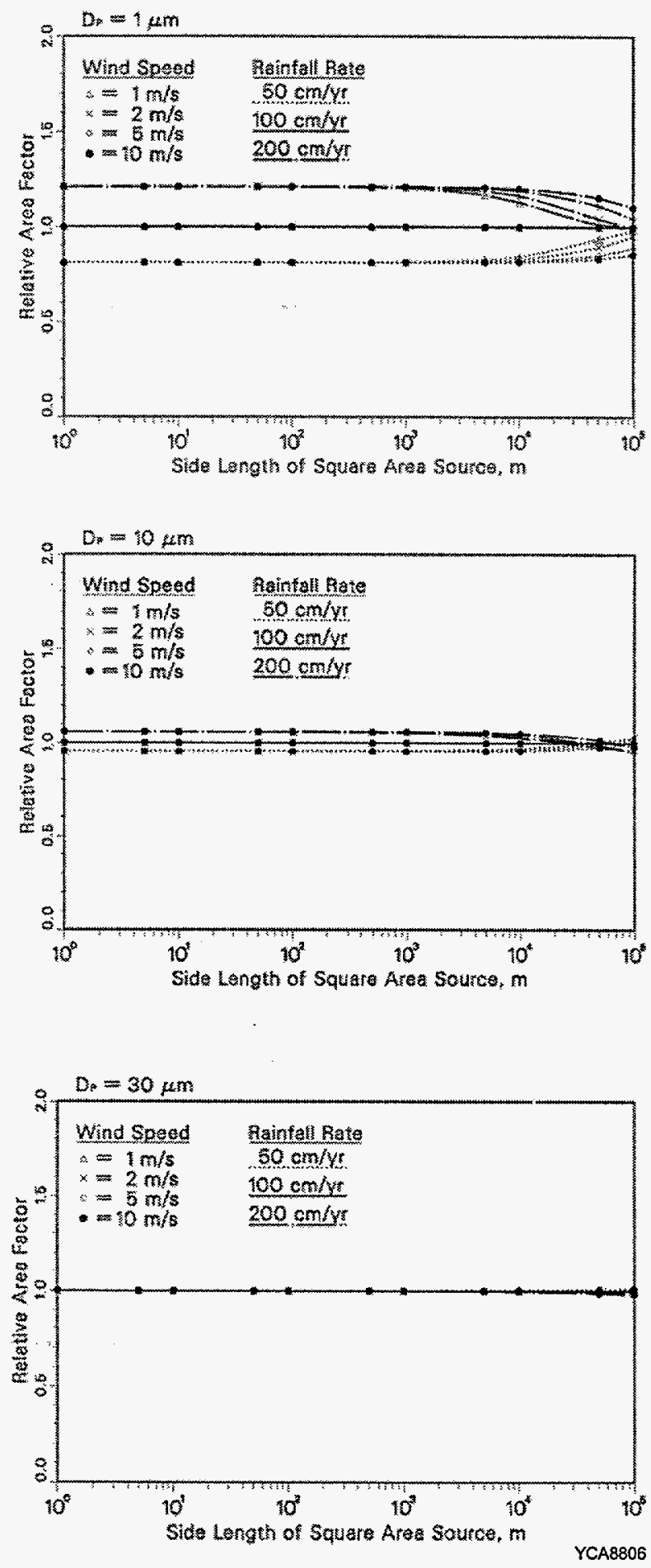

FIGURE 6 Relative Area Factors Associated with Perturbation of Rainfall Rate for $D_{p}=1,10$, and $30 \mu \mathrm{m}$ 

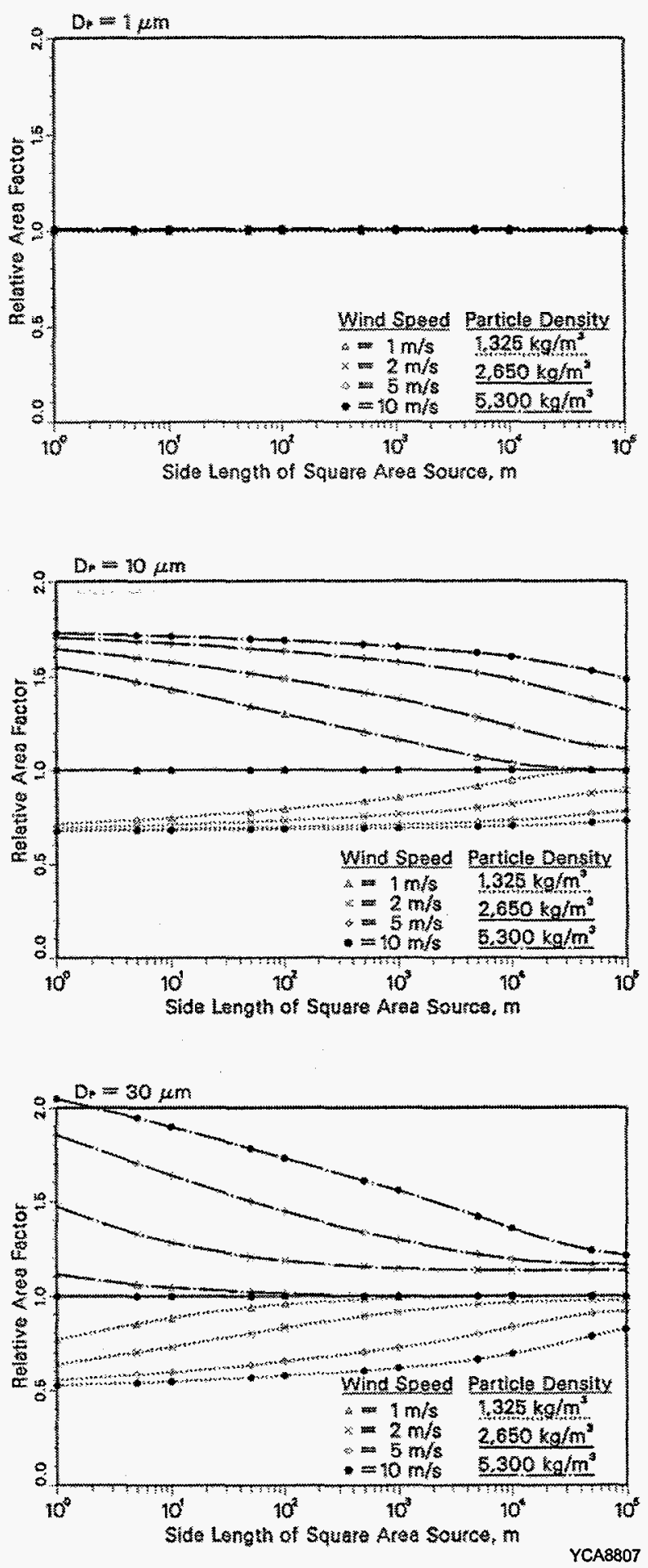

FIGURE 7 Relative Area Factors Associated with Perturbation of Particle Density for $D_{p}=1$, 10 , and $30 \mu \mathrm{m}$ 

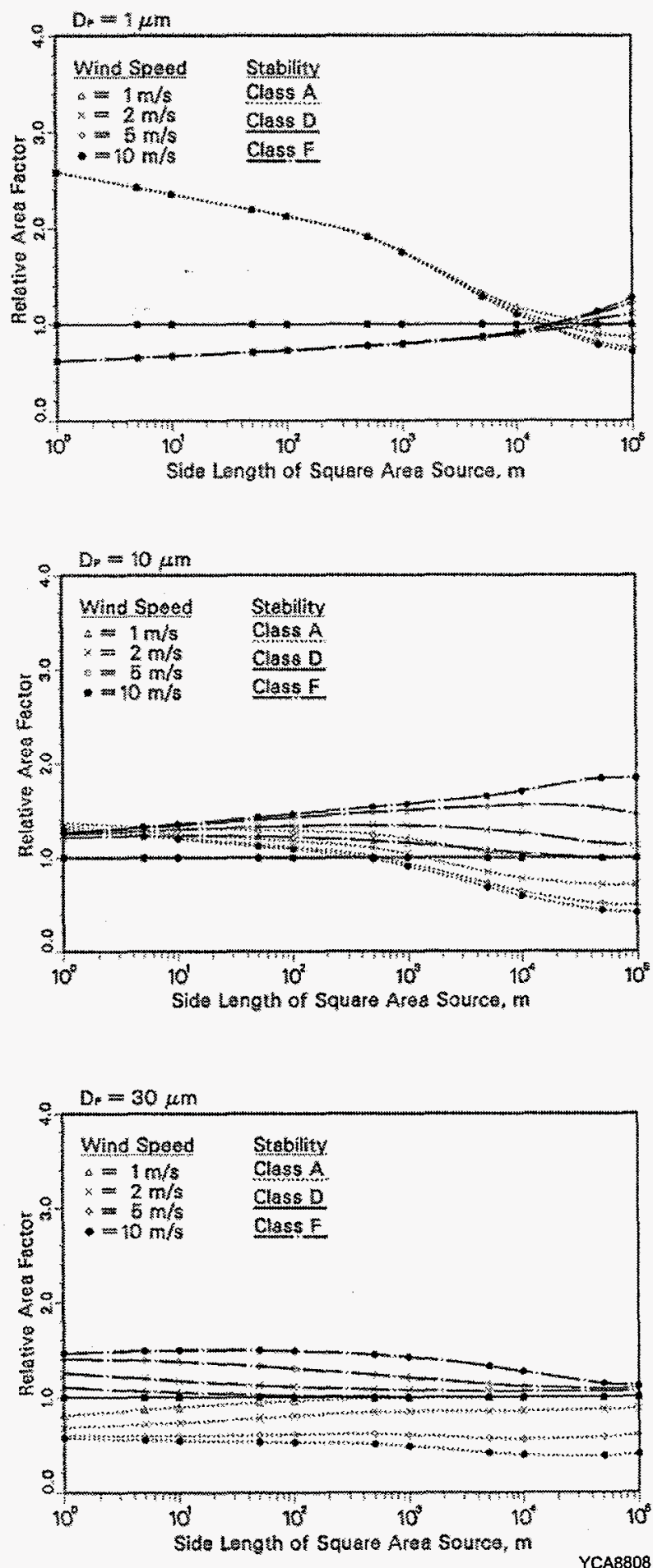

FIGURE 8 Relative Area Factors Associated with Perturbation of Stability Class for $D_{p}=1$, 10 , and $30 \mu \mathrm{m}$ 


\section{SUMMARY AND DISCUSSION}

The model described in this report was developed to improve the area factor used in older versions of the RESRAD code (Version 5.70 and older). The new model first approximates the onsite airborne concentrations of particulates emitted from an area source and subsequently calculates area factors as a function of particle diameter, wind speed, and side length of square area source. The assumptions made in developing the model include monodisperse particle size distributions, fixed particle density, fixed raindrop diameter, fixed annual rainfall rate, fixed atmospheric stability, and a neglect of the effect associated with radionuclide decay. Sensitivity analyses for the assumed fixed parameters indicate that the model provides reasonable results. Regression curves were developed for calculating area factors on the basis of the new model (Equation 15), which has been incorporated into RESRAD code version 5.75 and newer.

The new area factor is a function of particle size and wind speed. Because the inhalation dose conversion factors are for particles with an activity median aerodynamic diameter (AMAD) of $1 \mu \mathrm{m}$, the particle size is set to $1 \mu \mathrm{m}$ in the current version of RESRAD. However, the area factor routine is written with the flexibility to use actual particle size data if available in later versions of the RESRAD code. Wind speed is an input parameter of RESRAD. The code will use interpolation based on Equation 15 to calculate the area factor for the user input wind speed and the size of the contaminated zone.

The RESRAD code uses a mass loading factor and an area factor to estimate contaminant concentration in the air suspended from finite area soil sources. The default mass loading factor used in RESRAD 5.70 and older is $0.0002 \mathrm{~g} / \mathrm{m}^{3}$. This mass loading factor takes into account short periods of high mass loading and sustained periods of normal farmyard activities for which the dust level may be somewhat higher than ambient. Anspaugh et al. (1974) and Healy and Rodgers (1979) used $0.0001 \mathrm{~g} / \mathrm{m}^{3}$ for predictive purposes and found that the predicted results and the real cases were comparable. The EPA (1977) has used $0.0001 \mathrm{~g} / \mathrm{m}^{3}$ for screening calculations. Average ambient concentrations of transportable particles range from $3.3 \times 10^{-5}$ to $2.54 \times 10^{-4} \mathrm{~g} / \mathrm{m}^{3}$ in urban locations and from $9 \times 10^{-6}$ to $7.9 \times 10^{-5} \mathrm{~g} / \mathrm{m}^{3}$ in nonurban locations. The mass loading value will fluctuate above its ambient level depending on human activities such as plowing and cultivating dry soil or driving on an unpaved road. A default value of $0.0002 \mathrm{~g} / \mathrm{m}^{3}$ seems to be overly conservative (perhaps by a factor of about 2 to 10 ). To reduce the over-conservatism in the RESRAD code, the default mass loading factor has been changed from $0.0002 \mathrm{~g} / \mathrm{m}^{3}$ to $0.0001 \mathrm{~g} / \mathrm{m}^{3}$ for more realistic (yet for most conditions still conservative) prediction of dust loading.

The new default mass loading factor and the area factor allow RESRAD to predict realistically conservative contaminant concentrations in the air. Hence, the inhalation doses estimated are more realistic. However, if measurement data are available, the measured air contaminant concentrations data should be used in RESRAD analysis. 


\section{REFERENCES}

Abramowitz, M., and I.A. Stegun, 1964, Handbook of Mathematical Functions with Formulas, Graphs, and Mathematical Tables, National Bureau of Standards, Washington, D.C., June.

Anspaugh, L.R., et al., 1974, "Evaluation of the Resuspension Pathway toward Protective Guidelines for Soil Contamination with Radioactivity," presented at the International Atomic Energy Agency/World Health Organization Symposium on Radiological Safety Evaluation of Population Doses and Application of Radiological Safety Standards to Man and the Environment, Fortoraz, Yugoslavia, May 20-24.

Brady, N.C., 1974, The Nature and Properties of Soils, 8th ed., Macmillan Publishing Co., Inc., New York, N.Y.

EPA - See U.S. Environmental Protection Agency.

Gilbert, T.L., et al., 1983, Pathways Analysis and Radiation Dose Estimates for Radioactive Residues at Formerly Utilized MED/AEC Sites, ORO-832 (Rev.), prepared by Argonne National Laboratory, Division of Environmental Impact Studies, Argonne, Ill., for U.S. Department of Energy, Oak Ridge Operations, Oak Ridge, Tenn., March (reprinted with corrections: Jan. 1984).

Healy, J.W., and J.C. Rodgers, 1979, Limits for the Burial of the Department of Energy Transuranic Waste, LA-UR-79-100, Los Alamos Scientific Laboratory, Los Alamos, N.M.

Miller, A., and J.C. Thompson, 1970, Elements of Meteorology, Charles E. Merrill Publishing Co., Columbus, Ohio.

National Oceanic and Atmospheric Administration (NOAA), 1976, A Climatological Analysis of Pasquill Stability Categories Based on STAR Summaries, Asheville, N.C., National Climatic Center, April.

NOAA - See National Oceanic and Atmospheric Administration.

Snedecor, G.W., and W.G. Cochran, 1980, Statistical Methods, 7th ed., The Iowa State University Press, Ames, Iowa.

Turner, D.B., 1970, Workbook of Atmospheric Dispersion Estimates, Office of Air Programs Publication Number AP-26, U.S. Environmental Protection Agency, Research Triangle Park, N.C. 
Turner, D.D., 1994, Workbook of Atmospheric Dispersion Estimates: An Introduction to Dispersion Modeling, 2nd Ed., Lewis Publishers, Boca Raton, Fla.

U.S. Environmental Protection Agency, 1977, Proposed Guidance on Dose Limits for Persons Exposed to Transuranium Elements in the General Environment, Office of Radiation Programs, Criteria and Standards Division, Washington, D.C.

U.S. Environmental Protection Agency, 1995, User's Guide for the Industrial Source Complex (ISC3) Dispersion Models: Volume II - Description of Model Algorithms, Office of Air Quality Planning and Standards, Research Triangle Park, N.C., Sept.

Yu, C., et al., 1993, Manual for Implementing Residual Radioactive Material Guidelines Using RESRAD, Version 5.0, prepared by Argonne National Laboratory, Environmental Assessment Division, Argonne, Ill., for U.S. Department of Energy, Assistant Secretary for Environment, Safety, and Health, and Assistant Secretary for Environmental Restoration and Waste Management, Sept. 